\title{
Ossification of the vertebral column in human foetuses: histological and computed tomography studies
}

\author{
A. Skórzewska1 , M. Grzymisławska1, M. Bruska1 , J. Łupicka¹, W. Woźniak1,2 \\ ${ }^{1}$ Department of Anatomy, Poznan University of Medical Sciences, Poznan, Poland \\ ${ }^{2}$ Medical Faculty, Higher Vocational State School, Kalisz, Poland
}

[Received 13 March 2013; Accepted 18 April 2013]

There is no agreement in the literature as to the time of the onset and progress of the vertebral column ossification. The aim of the present study was to determine the precise sequence of ossification of the neural arches and vertebral centra. Histological and radiographic studies were performed on 27 human foetuses aged from 9 to 21 weeks. It was found that the ossification of vertebrae commences in foetuses aged 10 and 11 weeks. Ossification centres appear first for neural arches in the cervical and upper thoracic vertebrae and by the end of $11^{\text {th }}$ week they are present in all thoracic and lumbar neural arches. In the vertebral centra in foetus of 10 weeks ossification was found in the lower 7 thoracic and first lumbar vertebrae. By the end of $11^{\text {th }}$ week ossification is present in the lower 4 cervical, all thoracic, all lumbar and 4 sacral vertebral centra. The study indicates that ossification of the neural arches proceeds in the craniocaudal direction, whereas in the vertebral centra it progresses from the lower thoracic vertebrae into both directions. Different shapes of ossification centres were also described. (Folia Morphol 2013; 72, 3: 230-238)

Key words: human development, vertebral column, ossification

\section{INTRODUCTION}

The development of vertebrae, both as a tissue and as individual skeletal units, is a highly complicated subject that includes, among other aspects, chondrification and ossification, calcification and matrix deposition and resorption, and structure and growth [27, 30].

The time of the onset of ossification varies considerably in various bones, and ranges from the end of the embryonic period proper (mandible, humerus, and clavicle) to postnatal life (carpals and most tarsals). In vertebrae the cartilage calcifies and periosteal bone forms, and then vascular invasion and endochondral ossification begins [27].
Despite many histological, ultrastructural, ultrasonographic, and radiographic studies $[2-5,14,25$, $26,28]$, there is no agreement about the exact time of the onset and progress of ossification in the vertebral column and no hypothesis concerning different developmental pathways of centra and neural arches has been suggested. There are also different opinions as to the parts of the vertebral column in which the ossification commences. It has to be stressed that in order to determine the precise sequence and timing of developmental events, it is necessary to employ a system of proper staging [29].

Application of computed tomography (CT) in studies of development in human foetuses allows

Address for correspondence: Dr A. Skórzewska, Department of Anatomy, Poznan University of Medical Sciences, ul. Święcickiego 6 , 60-781 Poznań, Poland, tel: +48 6185465 48, e-mail: a.skorzewska@gmail.com 
to investigate the anatomical structures leaving them untouched. It permits to visualise the ossification centres of vertebrae in frontal and sagittal planes using multiplanar reformatted images and makes it possible to evaluate their number, size and shape. It also shows the distribution of calcified tissue in the vertebral centra and allows to distinguish different ossification patterns of them, as well as to recognise the anomalies of ossification if they occur in the foetal period. Performed histological study enables to ascertain the initial appearance of the ossification centres in particular parts of the vertebral column and establish the sequence of the onset of ossification. In the present study particular attention was paid to the shape and distribution of the developing ossification centres for the vertebral bodies.

\section{MATERIALS AND METHODS}

The study was performed on 27 human foetuses aged 9-21 weeks (33 to 198 C-R length). The embryos were from the collection of the Department of Anatomy, University of Medical Sciences in Poznan.

The foetuses, which had been obtained from histerotomies and spontaneous abortions were intact, without any obvious external abnormality, and had been fixed and preserved in formalin.

Different methods for demonstrating the appearance times of the ossification of vertebral column were used. Eleven foetuses aged 9-12 weeks (Table 1) after decalcification were embedded in toto in paraplast and serially sectioned in horizontal, frontal and sagittal planes. The sections were stained with haematoxylin and eosin, cresyl violet, Mallory's method and impregnated with silver.

Seven foetuses, aged 9-12 weeks (Table 2), were cleared with potassium hydroxide and stained with alizarin red. The strength of potassium hydroxide graded according to C-R length (0.25-0.5\%). All specimens were then passed from potassium hydroxide to pure glycerine until the soft tissues became completely transparent.

In 9 foetuses, aged 11-21 weeks (Table 3), CT was applied. The study was performed with the aid of Picker tomograph, the bony program with slice-thickness $1.5 \mathrm{~mm}$. Multiplanar reformatted images of vertebral column were performed. Number and shape of ossification centres in vertebrae were evaluated.

\section{RESULTS}

In foetuses aged 9 and 10 weeks all vertebrae are cartilaginous and the widest ones are cervical verte-
Table 1. Crown-rump length in millimetres and age in postovulatory weeks of serially sectioned foetuses

\begin{tabular}{lcc}
\hline Number & $\begin{array}{c}\text { Crown-rump } \\
\text { length [mm] }\end{array}$ & $\begin{array}{c}\text { Age in postovulatory } \\
\text { weeks }\end{array}$ \\
\hline 1 & 33 & 9 \\
2 & 35 & 9 \\
3 & 36 & 9 \\
4 & 45 & 10 \\
5 & 51 & 10 \\
6 & 53 & 10 \\
7 & 60 & 10 \\
8 & 63 & 11 \\
9 & 70 & 11 \\
10 & 75 & 12 \\
11 & 80 & 12 \\
\hline
\end{tabular}

Table 2. Crown-rump length in millimetres and age in postovulatory weeks of foetuses stained with alizarine red

\begin{tabular}{lcc}
\hline Number & $\begin{array}{c}\text { Crown-rump } \\
\text { length [mm] }\end{array}$ & $\begin{array}{c}\text { Age in postovulatory } \\
\text { weeks }\end{array}$ \\
\hline 1 & 36 & 9 \\
2 & 52 & 9 \\
3 & 60 & 10 \\
4 & 65 & 11 \\
5 & 68 & 11 \\
6 & 78 & 12 \\
7 & 82 & 12 \\
\hline
\end{tabular}

Table 3. Crown-rump length in millimetres and age in postovulatory weeks of foetuses used for computed tomography study

\begin{tabular}{lcc}
\hline Number & $\begin{array}{c}\text { Crown-rump } \\
\text { length [mm] }\end{array}$ & $\begin{array}{c}\text { Age in postovulatory } \\
\text { weeks }\end{array}$ \\
\hline 1 & 63 & 11 \\
2 & 75 & 12 \\
3 & 95 & 13 \\
4 & 105 & 14 \\
5 & 110 & 14 \\
6 & 126 & 15 \\
7 & 130 & 16 \\
8 & 161 & 18 \\
9 & 198 & 21 \\
\hline
\end{tabular}

brae (Fig. 1). The summit of the column is formed by the dens which consists of 2 parts (Fig. 2). From the junction between cervical and thoracic vertebrae, the diameter of the vertebrae gradually narrows (Fig. 3). 


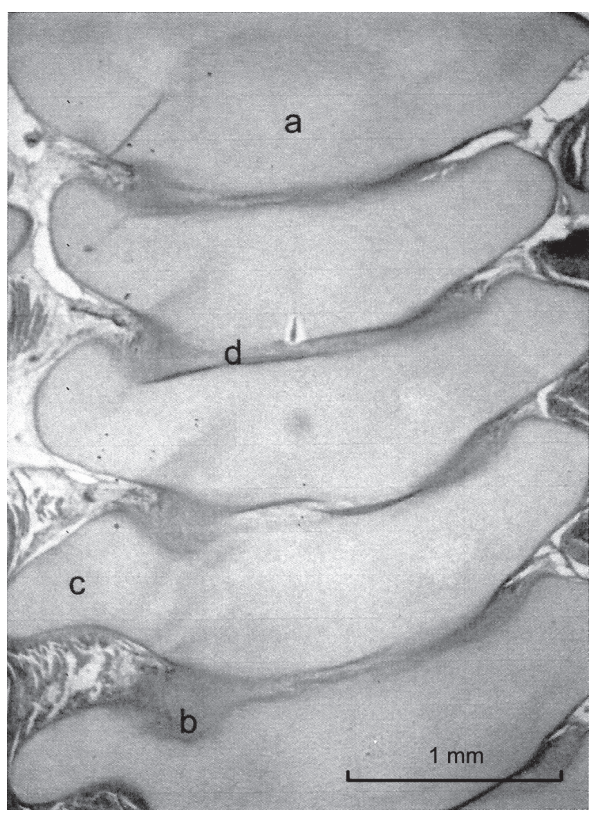

Figure 1. Foetus aged 10 weeks. Frontal section. Haematoxylin and eosin; $\mathrm{a}$ - vertebral centrum $\mathrm{C} 2 ; \mathrm{b}$ - intervertebral foramen; $\mathrm{c}$ - transverse process; $\mathrm{d}$ - intervertebral disc.

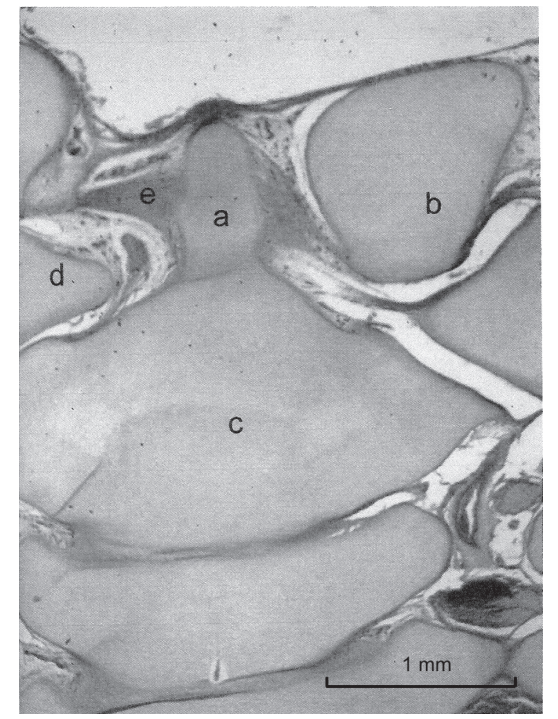

Figure 2. Foetus aged 10 weeks. Frontal section. Haematoxylin and eosin; a - dens of the axis; $b-$ ventral part of the atlas; $c-$ vertebral centrum of the axis; $d$ - part of the anterior arch of the atlas; $\mathrm{e}-$ transverse ligament of the atlas.

During the $9^{\text {th }}$ week the neural arches are fused in the cervical and the upper and midthoracic regions of the vertebral column. Fusion of the neural arches in the lower thoracic and lumbar vertebrae is seen in foetuses at 10 weeks. All cartilaginous ribs are clearly delineated and the primary ossification centres appear near the angle of the rib during the $9^{\text {th }}$ week.

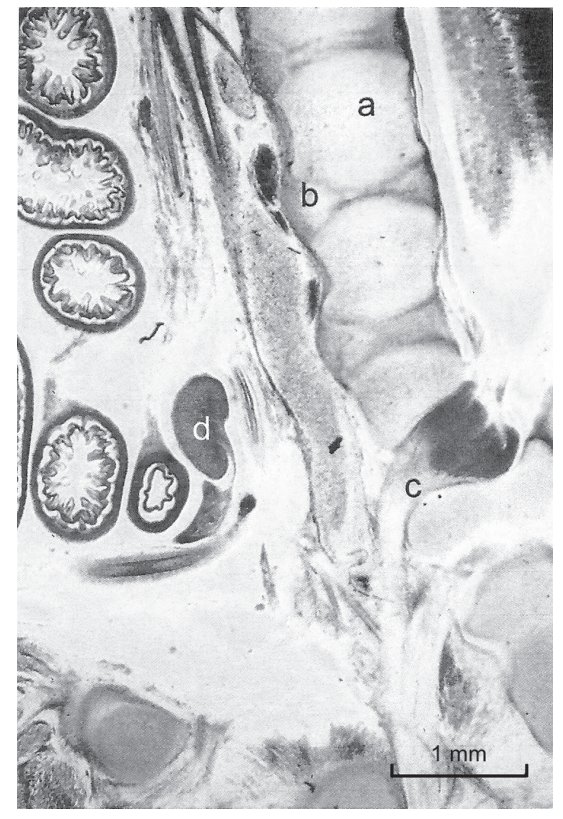

Figure 3. Foetus aged 10 weeks. Sagittal section. Mallory's staining; a - vertebral centrum; b - intervertebral disc; $c$ - spinal nerve $L 4 ; \mathrm{d}$ - gonad.

Beginning from the $11^{\text {th }}$ week, the width of vertebrae from the $2^{\text {nd }}$ cervical to $6^{\text {th }}$ thoracic gradually decreases. The first cervical vertebra is the widest in all the histologically investigated foetuses. The lower thoracic and lumbar vertebrae increase in width.

Ossification of vertebrae commences in foetuses at the end of the $10^{\text {th }}$ week (C-R length $60 \mathrm{~mm}$ ) and at the beginning of the $11^{\text {th }}$ week (C-R length $63 \mathrm{~mm}$ ).

In these foetuses the ossification centres were present one for each half of the neural arch in the cervical and upper thoracic vertebrae and one for the centrum in the lower 7 thoracic and first lumbar vertebrae (Fig. 4). By the end of the $11^{\text {th }}$ week the remaining thoracic and all lumbar neural arches ossify. Ossification of the vertebral centra in the lower 4 cervical, all thoracic, all lumbar and 4 sacral vertebrae was observed also during the $11^{\text {th }}$ week.

In the CT study of foetus aged 11 weeks, ossification centres for neural arches were observed in all cervical, thoracic and lumbar vertebrae (Figs. 5, 6). Ossification centres for vertebral centra in this foetus were observed in the lower 2 cervical, all thoracic, all lumbar and upper 3 sacral vertebrae (Figs. 6-9). In foetus aged 12 weeks vertebral centra of the lower 3 cervical vertebrae commence ossification (Fig. 10). The ossification of vertebral centra in the upper cervical vertebrae (C2-C4) was visible in foetus aged 13 weeks. 


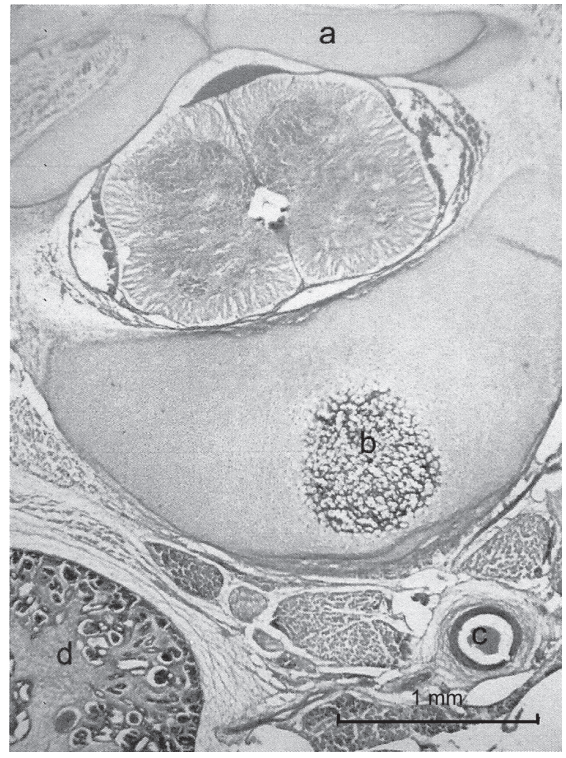

Figure 4. Foetus aged 11 weeks. Horizontal section. Haematoxylin and eosin; $a$ - neural arch; $b$ - ossification centre for vertebral centrum; c - aorta; $d$ - kidney.

The ossification of neural arches of the sacral vertebrae was not evident until the $14^{\text {th }}$ week. In foetus aged 18 weeks ossification centres were visible in the neural arches of the upper 3 sacral vertebrae. In foetus at $21^{\text {th }}$ week ossification centres for vertebral centra and for neural arches of the $5^{\text {th }}$ sacral vertebra appeared. It is evident from the study that in the sacral vertebrae the vertebral centra ossified first, and the neural arches complete the ossification afterwards. In the cervical vertebrae the neural arches ossify first. The CT study revealed that the ossification centres for vertebral centra had different shape in particular regions of the vertebral column (Table 4). In the cervical and sacral regions they were rounded and oval (Figs. 11, 12). This was particularly evident in the older investi-

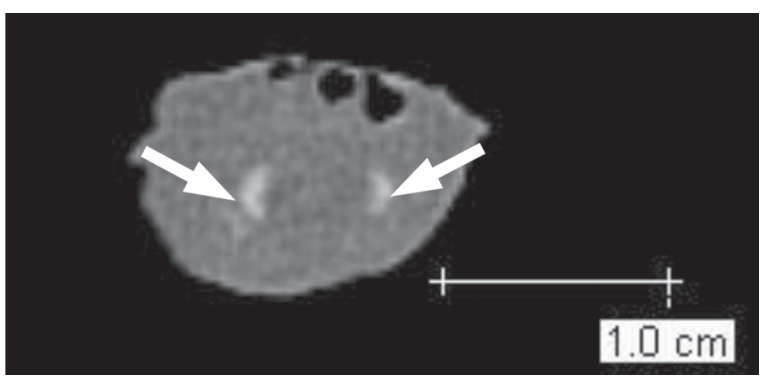

Figure 5. Foetus aged 11 weeks. Ossification centres for neural arches of vertebra C2 (arrows).

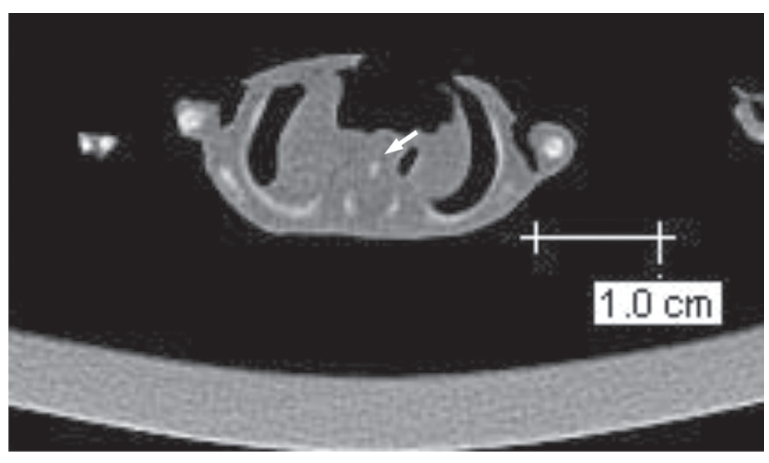

Figure 6. Foetus aged 11 weeks. Ossification centres for neural arches and vertebral centrum (arrow) of vertebra T4.

gated foetuses. In the thoracic and lumbar regions the ossification centres varied in shape. They were oval, mushroom-like (Fig. 13), in the shape of horizontally oriented letter H (Fig. 14), C-shaped (Fig. 15) or in the shape of horizontally oriented letter U (Fig. 16).

Transverse slices and reconstructions in sagittal plane showed that the ossification centres for vertebral centra T3-S1 in foetus aged 18 weeks consist of 2 parts - larger anterior and smaller posterior (Fig. 17). These both parts were completely separated (Figs. 18-20).

Table 4. Appearance and shape of ossification centres in vertebral centra in particular parts of the vertebral column in computed tomography

\begin{tabular}{lcccc}
\hline Age in postovulatory weeks & Cervical vertebrae & Thoracic vertebrae & Lumbar vertebrae & Sacral vertebrae \\
\hline 11 & C6, C7 round & T1-T12 round & L1-L5 round & S1-S3 round \\
12 & C5-C7 round & T1-T12 round & L1-L5 round & S1 round \\
13 & C2-C7 round & T1-T12 mushroom-like & L1-L5 mushroom-like & S1-S4 oval \\
14 & C2-C7 round & T1-T12 mushroom-like & L1-L5 mushroom-like & S1-S4 round \\
14 & C2-C7 round & T1-T12 mushroom-like & L1-L5 mushroom-like & S1-S4 round \\
15 & C2-C7 round & T1-T12 mushroom-like & L1-L5 mushroom-like & S1-S4 oval \\
16 & C2-C7 round & T1-T12 mushroom-like & L1-L5 mushroom-like & S1-S4 oval \\
18 & C2-C7 oval & T1-T12 irregular & L1-L5 irregular & S1-S4 oval \\
21 & C2-C7 round & T1-T12 oval & L1-L5 oval & S1-S4 round \\
\hline
\end{tabular}




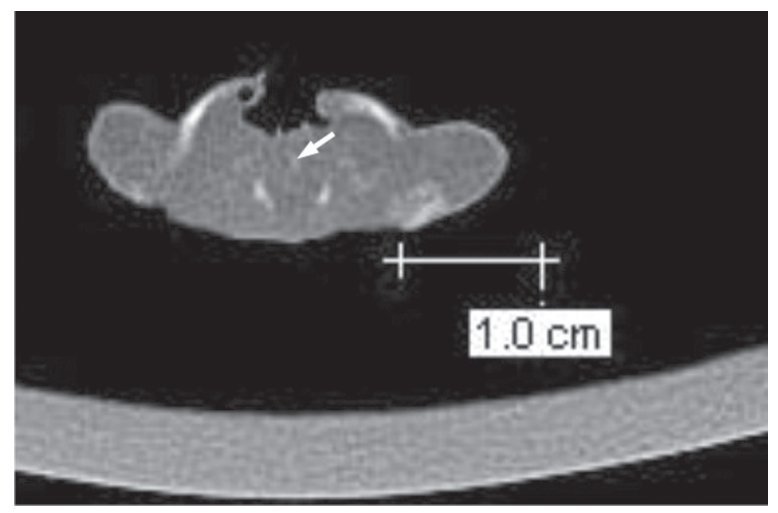

Figure 7. Foetus aged 11 weeks. Ossification centres for neural arches and vertebral centrum (arrow) of vertebra C6.

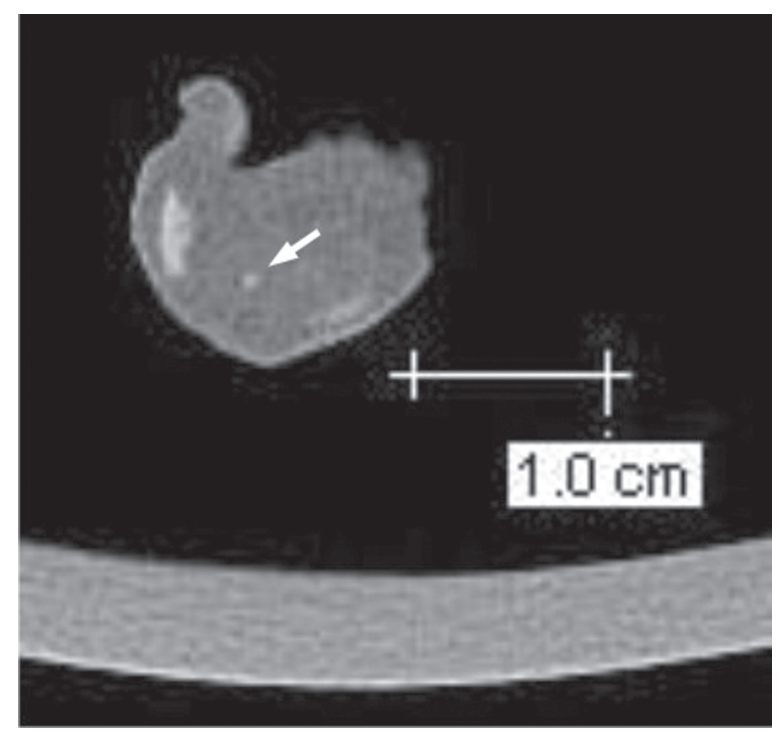

Figure 8. Foetus aged 11 weeks. Ossification centre for vertebral centrum S2 (arrow).

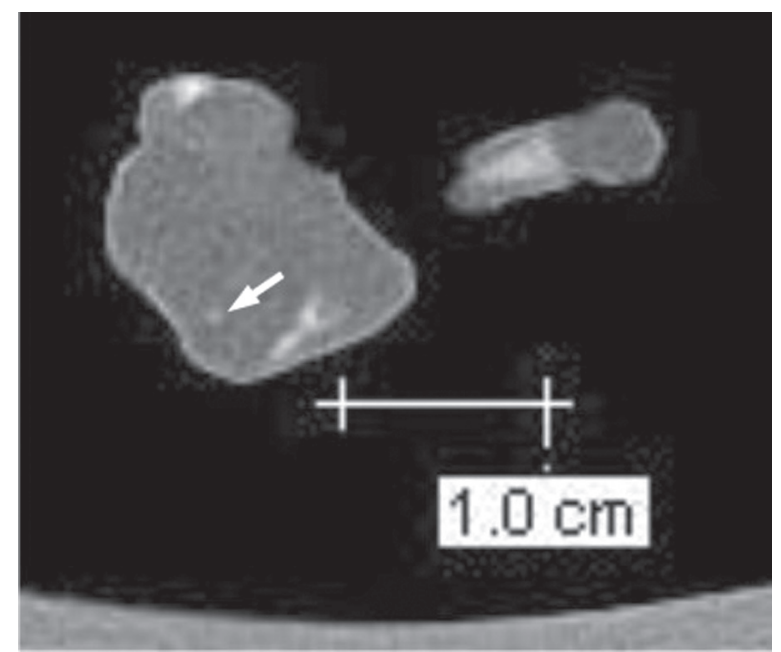

Figure 9. Foetus aged 11 weeks. Ossification centre for vertebral centrum S3 (arrow).

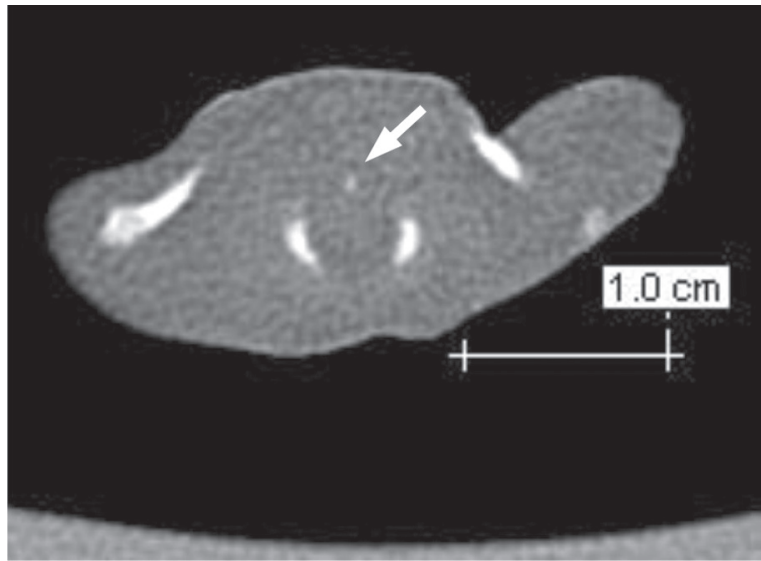

Figure 10. Foetus aged 12 weeks. Ossification centres for vertebral centrum (arrow) and neural arches of vertebra C5.

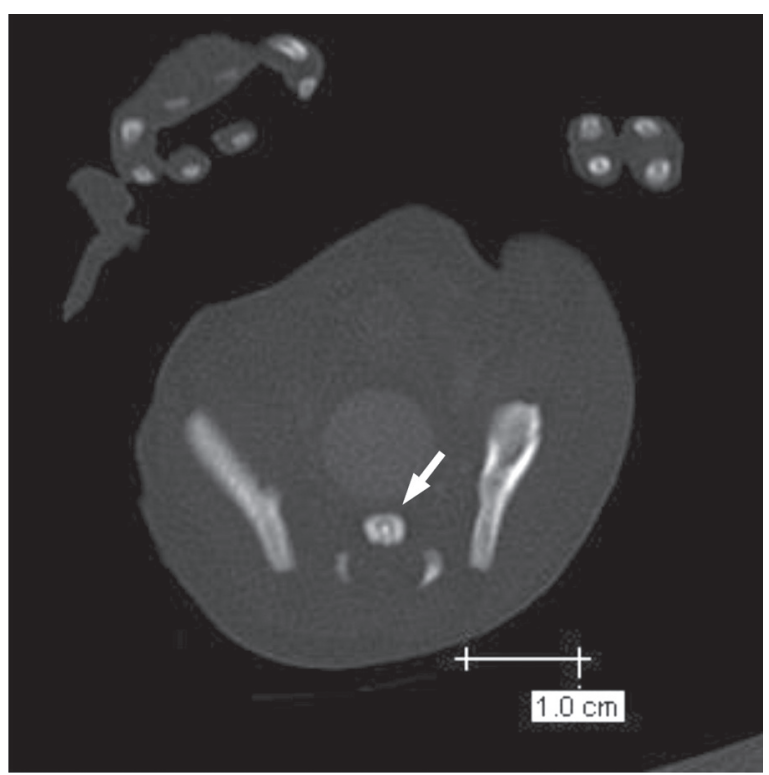

Figure 11. Foetus aged 18 weeks. Round ossification centre for vertebral centrum S1 (arrow).

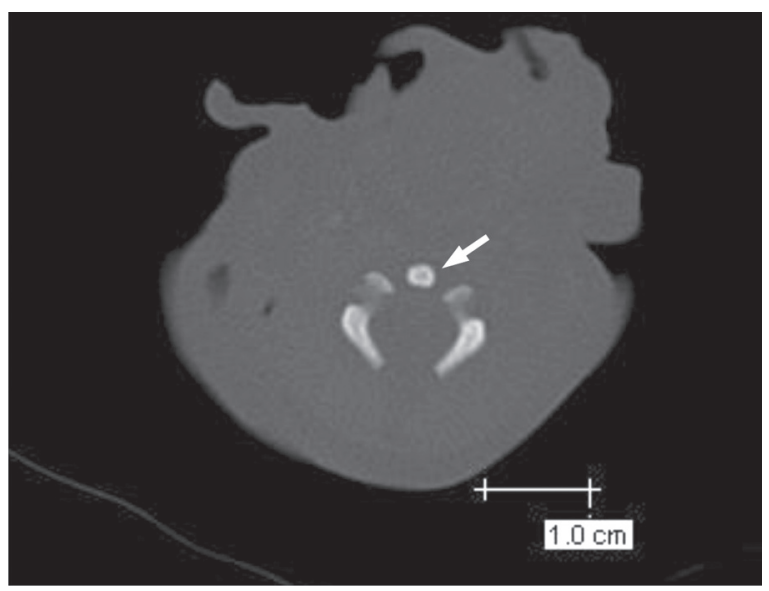

Figure 12. Foetus aged 21 weeks. Oval ossification centre for vertebral centrum C2 (arrow) in foetus aged 21 weeks. 


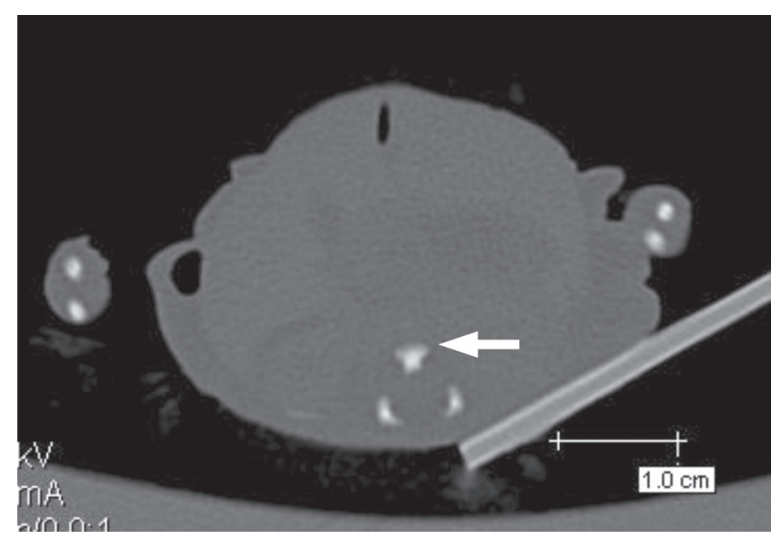

Figure 13. Foetus aged 16 weeks. Mushroom-like ossification centre for vertebral centrum T6 (arrow).

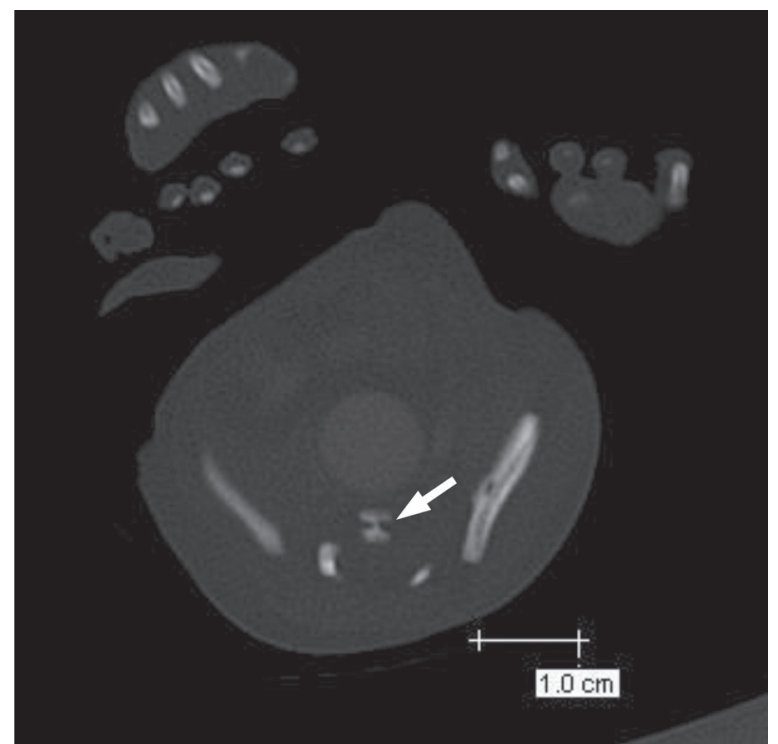

Figure 14. Foetus aged 18 weeks. Ossification centre for vertebral centrum L5 (arrow) resembling the shape of horizontally oriented letter $\mathrm{H}$.

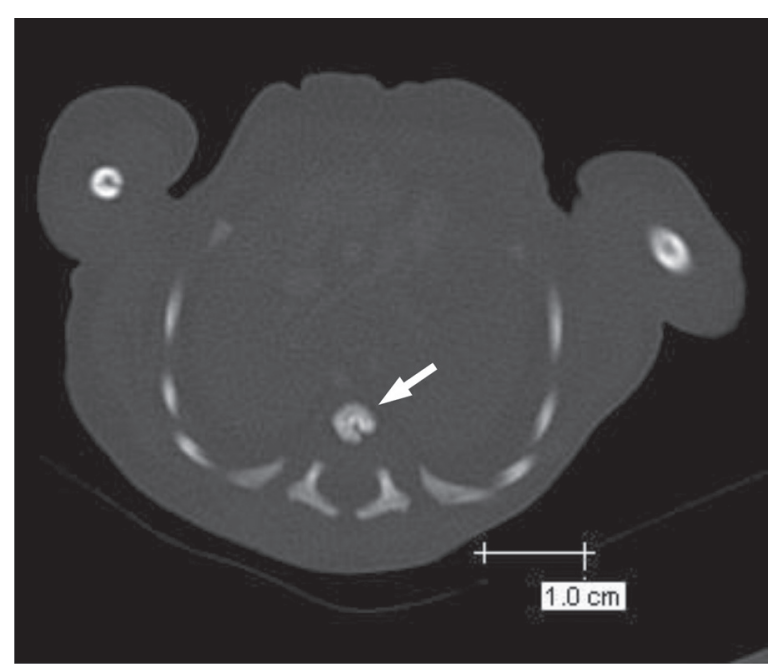

Figure 15. Foetus aged 18 weeks. C-shaped ossification centre for vertebral centrum T4 (arrow).

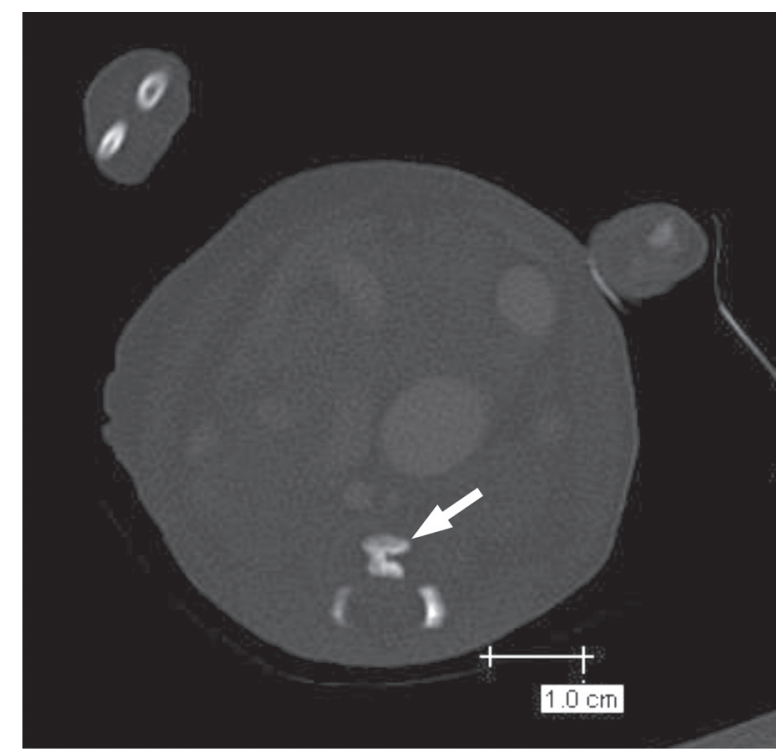

Figure 16. Foetus aged 18 weeks. Ossification centre for vertebral centrum L2 (arrow) resembling the shape of horizontally oriented letter $\mathrm{U}$.

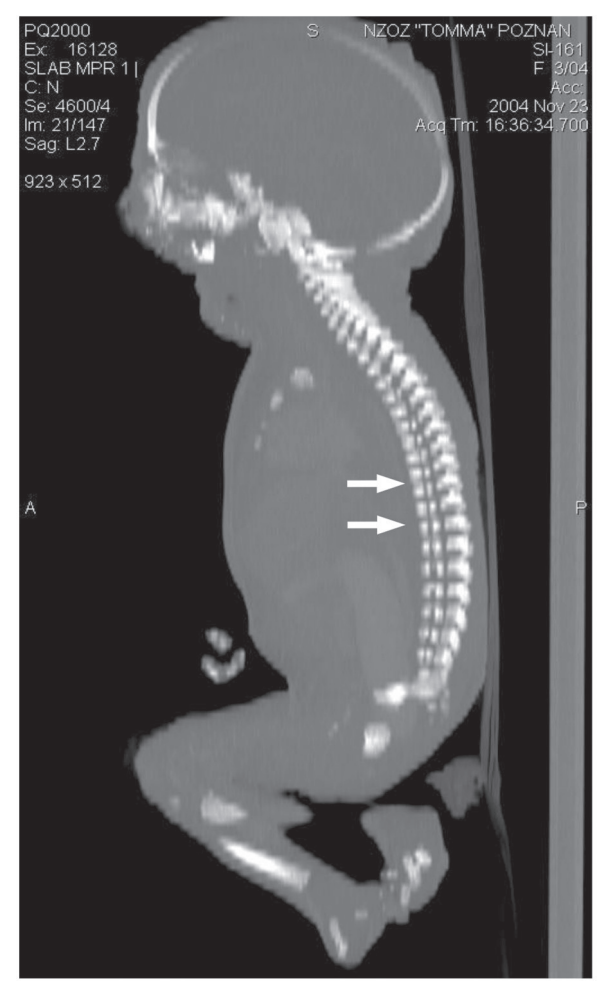

Figure 17. Foetus aged 18 weeks. Multiplanar reformatted image in sagittal plane reveals coronal cleft in thoracic and lumbar vertebrae (arrows).

\section{DISCUSSION}

The vertebrae develop from somites which are mesenchymal segments in paraxial mesoderm arranged in the right and left longitudinal rows on each side of 


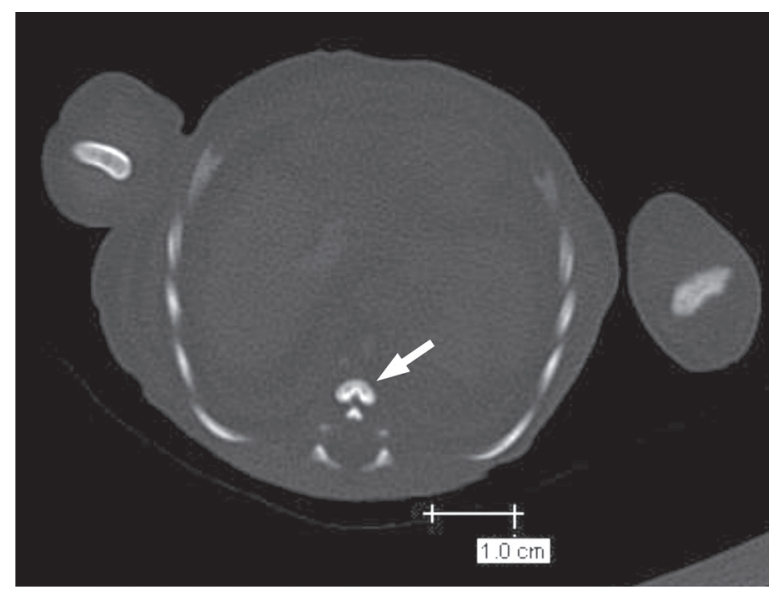

Figure 18. Foetus aged 18 weeks. Ossification centre for vertebral centrum T8 (arrow) consists of larger anterior and smaller posterior part.

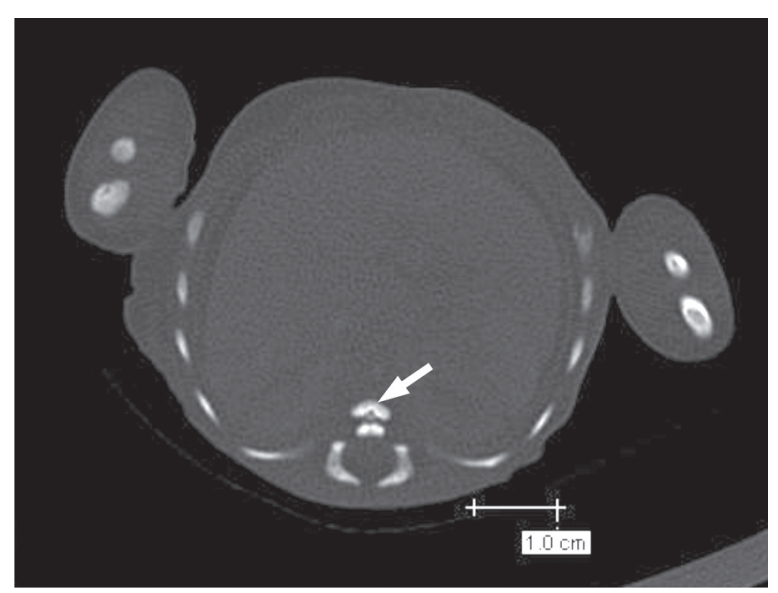

Figure 19. Foetus aged 18 weeks. Ossification centre for vertebral centrum T10 (arrow) consists of 2 separated parts.

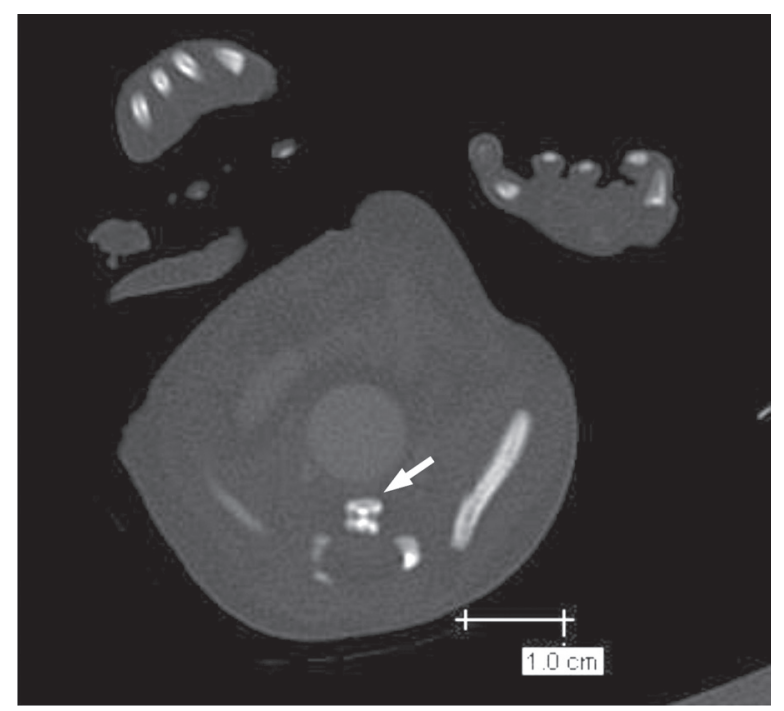

Figure 20. Foetus aged 18 weeks. Two parts of ossification centre for vertebral centrum of L4 (arrow). the neural tube and notochord and differentiate into 3 portions: 1) the sclerotome, 2) the myotome, and 3) the dermatome [30, 31]. The sclerotomes which proliferate in the medioventral wall of the somites participate in the formation of the vertebral column. All structures in the neighbourhood of the somites, such as the notochord, neural tube, surface ectoderm, and lateral mesoderm, influence formation and differentiation of the somites $[9,16]$. Based on experiments, it has been suggested that somites acquire regional specificity during early stages of segmentation. In this process Hox genes and retinoic acid play an important role [20]. The inductive signals have been identified as cell surface and extracellular matrix-associated proteins encoded by members of the Wnt gene family. The vertebral bodies are induced through the substances secreted by the notochord and the floor plate of the neural tube (Shh peptide), whereas induction of vertebral arches also requires interaction with the surface ectoderm through BMP-4 protein [20, 24]. The notochord and sclerotomes are key features in the development of the vertebral column.

According to Balling at al. [1], the Pax genes play important role in the development of sclerotomes which gradually surround the notochord. These genes are significant in patterning of sclerotomes, development of the perinotochordal sheath and development of the intervertebral disc [36, 39]. Reduced expression of PAX-1 gene causes reduction in the number of vertebral bodies and rib heads [21, 39]. The notochord induces both the development of the neural tube and the formation of the axial skeleton.

Types of vertebrae are specified very early in development and are related to intrinsic properties of their somatic precursors. Thoracic somites transplanted into the cervical or lumbar regions form typical thoracic vertebrae and ribs develop [11, 15, 20].

Various vertebral anomalies may appear early in the embryonic period. The split notochord syndrome may arise in the $3^{\text {rd }}$ week, when the notochordal process appears $[27,30]$. Butterfly vertebrae or hemivertebrae may develop during somitogenesis in the $5^{\text {th }}$ week. Vertebral bars as the remnants of vertebral continuity arise from stage 21 into the early foetal period [27, 30].

Chondrification of the vertebral column begins at the $6^{\text {th }}$ week and is well advanced during the $8^{\text {th }}$ and $9^{\text {th }}$ week $[27,34,35,38]$.

There is no agreement among the investigators as to the onset of ossification in the vertebral centra and neural arches [2, 3, 6, 29]. Noback and Robertson [25] 
observed ossification centres in foetuses aged 8 weeks (38 mm crown-rump length). O'Rahilly and Meyer [29] encountered ossification centra for the vertebral centra in foetuses aged 10 weeks ( $54 \mathrm{~mm}$ crown-rump length) and they stated that the ossification did not proceed rostrocaudally, but in general order thoracic, lumbar, and cervical. Radiographic study of Bagnall et al. [2,3] revealed that in foetuses aged 10 weeks the ossification centra for neural arches appeared in all cervical, all thoracic and upper 3 lumbar vertebrae. Ossification of vertebral centra in foetuses of 10 weeks was present in some of them, in the thoracic and lumbar region. These authors advanced the opinion that the extrinsic factors, such as mechanical action of muscles and active foetal movements may have an important influence on the progress of the ossification.

Barregi et al. [5] observed first appearance of the ossification centres for both vertebral centra and neural arches in foetuses of crown-rump length $45 \mathrm{~mm}$, what corresponds to 10 weeks of age. However, these authors designated such foetuses to the age group of 8 weeks.

In the performed histological and radiographic studies it was found that the ossification of vertebrae commences in foetuses aged 10 and 11 weeks. In these foetuses ossification centres appear first for neural arches in the cervical and upper thoracic vertebrae and by the end of the $11^{\text {th }}$ week they are present in all thoracic and lumbar neurial arches. In the vertebral centra in foetus aged 10 weeks ossification was found in the lower 7 thoracic and first lumbar vertebrae. This indicates that the ossification of the neural arches proceeds in the craniocaudal direction. The ossification of vertebral centra progresses from the lower thoracic region to both caudocranial and craniocaudal directions. The number of ossification centres for vertebral bodies and neural arches observed in this study confirms Bagnall et al. [3] observations. Kosa and Castellana [17] suggest that distinct morphological pattern is characteristic for individual groups of vertebrae and is constant during development. Nolting et al. [26] consider that the shape of ossification centres for thoracic vertebral centra changes during the foetal period from round to oval with transitional stage, when "mushroom-like" shape is noted. The feature of ossification centres revealed in this study in foetus aged 18 weeks is known as coronal vertebral cleft [32, 33]. According to Tanaka and Unthoff [37], it can be considered as a variant of normal endochondral ossification as well as non-homogenous pattern of ossification of vertebral centra observed in foetus aged 21 weeks. Sagittal and coronal bands of uncalcified tissue occur in newborns, most frequently in lumbar region of the vertebral column, and usually disappear through the $1^{\text {st }}$ and $2^{\text {nd }}$ year postnatally. Coronal vertebral clefts may appear in congenital malformations of skeletal system [42], such as Desbuquois dysplasia [10], atelosteogenesis [18], chondrodysplasia punctata [12, 41], dyssegmental dysplasia [13], Kniest dysplasia [19], short rib polydactyly syndrome, Larsen's syndrome $[8,40]$, humero-spinal dysostosis [7], dysplastic cortical hyperostosis (Kozłowski-Tsuruta syndrome) [23] or in patients with deletions $22 q 11$ [22]. In these cases multiple anomalies are observed including craniofacial abnormalities, shortening of long bones, anomalies of vertebrae (hemivertebrae, butterfly vertebrae, hypoplastic vertebrae), supernumerary ribs, polydactyly and congenital disorders of internal organs (pulmonary hypoplasia, hepatomegaly, congenital heart diseases).

In the present study in foetus aged 18 weeks 2 parts of the ossification centre were observed without additional abnormalities of the skeletal system. It supports the view that coronal cleft of vertebrae observed in this foetus was the developmental variant rather than the malformation. It is known that congenital malformation of skeletal system may be found in later stages of the development, when the ossification is more advanced. It concerns especially anomalies of epiphyseal regions of the long bones.

\section{REFERENCES}

1. Balling R, Helwig U, Nadeau J, Neubuser A, Schmahl W, Imai K (1996) Pax genes, and skeletal development. Ann NY Acad Sci, 785: 27-33.

2. Bagnall $K M$, Harris PF, Jones PRM (1977) A radiographic study of the human fetal spine. 1. The development of the secondary cervical curvature. J Anat, 123: 777-782.

3. Bagnall KM, Harris PF, Jones PRM (1977) A radiographic study of the human fetal spine. 2 . The sequence of development of ossification centres in the vertebral column. J Anat, 124: 791-602.

4. Bagnall KM, Harris PF, Jones PRM (1982) A radiographic study of the growth in width of the human fetal vertebral column. Anat Rec, 204: 265-262

5. Barregi R, Grill V, Zweyer M, Narducci P, Forabosco A (1994) A quantitative study on the special and temporal ossification patterns of vertebral centra and neural arches and their relationship to the fetal age. Ann Anat, 176: 311-317.

6. Budorick NE, Pretorius DH, Garfe MR, Lou KV (1991) Ossification of the fetal spine. Radiology, 181: 561-565.

7. Cortina H, Vidal J, Vallancera A, Alberto C, Muro D, Dominiguez F (1979) Humero-spinal dysostosis. Pediat Radiol, 8: 188-190. 
8. Currarino G (1986) Unusual bone dysplasia featuring severe platyspondyly and vertebral "coronal cleft" in infancy, and changes of metaphyseal chondrodysplasia in childchood. Pediat Radiol, 16: 433-436.

9. Dietrich S, Schubert FR, Lumsden A (1997) Control of dorsoventral pattern in the chick paraxial mesoderm. Development, 124: 3895-3908.

10. Faivre L, Cormier-Daire V, Eliott AM, Field F, Munnich A, Martoeaux P, Le Merrer M, Lachman R (2004) Desbuquois dysplasia, a reevaluation with abnormal and "normal" hands: radiographic manifestations. Am J Med Genet, 124: 48-53.

11. Goldstein RS, Kalcheim C (1992) Determination of epithelial half-somites in skeletal morphogenesis. Development, 116: 441-445.

12. Gilbert EF, Opitz JM, Spranger JW, Langer LO, Wolfson JJ, Viseskul C (1976) Chondrodysplasia punctate: rhizomelic form. Pathologic and radiologic studies of three infants. Eur J Pediat, 123: 89-109.

13. Handmaker SD, Campbell JA, Robinson LD, Chinwah O, Gorlin RJ (1977) Dyssegmental dwarfizm: a new syndrome of lethal dwarfism. Birth Defects, 13: 79-90.

14. Harten van der HJ, Brons JT, Schipper NW, Dijkstra PF, Meijer CJ, van Geijn HP (1990) The prenatal development of the normal human skeleton: a combined ultrasonographic and post-mortem radiographic study. Pediat Radiol, 21: 52-56.

15. Kieny M, Meuger A, Sengel P (1972) Early regionalization of the somatic mesoderm as studied by the development of the axial skeleton of the chick embryo. Dev Biol, 28: 142-161.

16. Kjaer I, Kjaer TW, Gravem N (1998) Ossification sequence of occipital bone and vertebrae in human fetuses. J Craniofac Genet Dev Biol, 13: 83-88.

17. Kosa F, Castellana C (2005) New forensic anthropological approachment for the age determination of human fetal skeletons on the base of morphometry of vertebral column. Foren Sci Int 147: 69-74.

18. Kuwashima S, Nishimura G, Kikushima H, Tanaka G, Furukawa T, Fujioka M (1992) Atelosteogenesis type 3: the first patient in Japan and survivor for more than 1 year. Acta Paediat Jpn, 34: 543-546.

19. Langer LO, Gonzales-Ramos M, Chen H, Espritu CE, Courtney NW, Opitz JM (1976) A severe infantile micromelic chondrodysplasia which resembles Kniest disease. Eur J Pediat, 123: 29-38.

20. Larsen WJ (2001) Human embryology. $3^{\text {rd }}$ Ed. Churchill Livingstone, New York, Edinburgh, London, Philadelphia.

21. Lopez BC, David KM, Crockard HA (1997) Inadequate Pax-1 gene expression as a cause of agenesis of the thoracolumbar spine with failure of segmentation. J Neurosurg, 86: 1018-1021.

22. Ming JE, McDonald-McGinn DM, Megerian TE, Driscoll DA, Elias ER, Russell BM, Irons M, Emanuel BS, Markowitz RI, Zackai EH (1997) Skeletal anomalies and deformities in patients with deletions of 22q11. Am J Med Genet, 72: 210-215.
23. Monish Suri, Garret C, Winter RM, Hall CM, Griffiths M (2002) Dysplastic cortical hyperostosis (Kozlowski-Tsuruta syndrome): report of the second case. Clin Dysmorphol, 11: 267-270.

24. Monsoro-Burgh AH, Duprez D, Watanabe $Y$, Bontoux M (1996) The role of bone morphogenetic proteins in vertebral development. Development, 122: 3007-3014.

25. Noback CR, Robertson GG (1951) Sequences of appearance of ossification centers in the human skeleton during the first five prenatal months. Am J Anat, 89: 1-28.

26. Nolting D, Hansen BF, Kesling JK, Kjaer I (1998) Prenatal development of the normal human vertebral corpora in different segments of the spine. Spine, 23: 2265$-2271$.

27. O'Rahilly R, Benson DR (1985) The development of the vertebral column. In: Bradford DS, Hensinger RM eds. The pediatric spine. Thieme, New York, pp. 3-17.

28. O'Rahilly R, Meyer DB (1956) Roentgenographic investigation of the human skeleton during early fetal life. Am J Roentgenol Radium Ther Nucl Med, 76: 455-468.

29. O'Rahilly R, Meyer DB (1979) The timing and sequence of events in the development of the human vertebral column during the embryonic period proper. Anat Embryol, 157: 167-176.

30. O'Rahilly R, Müller F (2001) Human embryology and teratology. 3rd Ed. John Willey and Sons, Inc. Publ. New York, Chichester, Wienheim, Brisbane, Singapore, Toronto.

31. O'Rahilly R. Müller F. (2003) Somites, spinal ganglia, and centra. Cells Tiss Org, 174: 75-92.

32. Reichmann S, Lewin T (1969) Coronal cleft vertebrae in growing individuals. A preliminary report. Acta Orthop Scandinav, 40: 3-22.

33. Riggio S, Burroni M, Merli A (1976) Frontal vertebral cleft in the newborn. Minerva Med, 67: 1413-1416.

34. Sensenig EC (1951) The early development of the meninges of the spinal cord on human embryos. Contr Embryol Carneg Instn, 34: 145-157.

35. Sensenig EC (1957) The development of the occipital and cervical segments and their associated structures in human embryos. Contr Embryol Carneg Instn, 36: 141-152.

36. Smith CA, Tuan RS (1994) Human PAX gene expression and development of the vertebral column. Clin Orthop, 302: $241-250$

37. Tanaka T, Unthoff HK (1983) Coronal cleft of vertebrae, a variant of normal enchondral ossification. Acta Orthop Scand, 54: 389-395.

38. Tondury G (1958) Entwicklungsgeschichte und Fehlbildungen der Würbelsäule. Hippokrates, Stuttgart 1952.

39. Verbout AJ (1985) The development of the vertebral column. Adv Anat Embryol Cell Biol, 90: 1-122.

40. Weisenbach J, Melegh B (1996) Vertebral anomalies in Larsen's Syndrome. Pediat Radiol, 26: 682-683.

41. Wells TR, Landing BH, Bostwick FH (1992) Studies of vertebral coronal cleft in rhizomelic chondrodysplasia punctata. Pediat Pathol, 12: 593-600.

42. Westvik J, Lechman R (1998) Coronal and sagittal clefts in skeletal dysplasias. Pediat Radiol, 28: 764-770. 